\title{
GOBIO GENUS SPECIES INTEGRATED MANAGEMENT SYSTEM - TÂRNAVA RIVERS STUDY CASE (TRANSYLVANIA, ROMANIA)
}

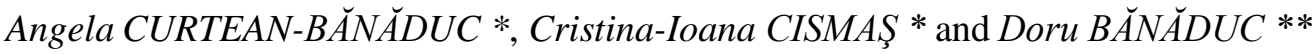 \\ * "Lucian Blaga" University of Sibiu, Faculty of Sciences, Dr. Ion Raţiu Street 5-7, Sibiu, Sibiu County, \\ Romania, RO-550012, angela.banaduc@ulbsibiu.ro, cristha_83@yahoo.com \\ ** "Lucian Blaga” University of Sibiu, Applied Ecology Research Center, Dr. Ion Raţiu Street 5-7, \\ Sibiu, Sibiu County, Romania, RO-550012, ad.banaduc@yahoo.com/Broward College, 3501 SW Davie \\ Road, Davie, Florida, USA, dbanaduc@broward.edu
}

DOI: 10.2478/trser-2019-0007

KEYWORDS: Gobio kessleri, Gobio albipinnatus, Gobio gobio, habitat needs, human activities preassures and threats, management, lotic habitats improvement, Târnava Mare River, Târnava Mică River, Târnava River, Transylvania, Romania, European Union.

\section{ABSTRACT}

The lotic habitats quality indicative congeners species Gobio gobio, Gobio kessleri and Gobio albipinnatus populations' dynamic in time (2004-2019) and space revealed a decreasing trend in these rivers ecological status. The ADONIS:CE tool has been used to build a backing management system model, based on these indicative fish species habitat needs, indicators for favourable conservation status, pressures and threats. This management system implementation in the field will favour the amelioration of lotic habitats and the ecological status recovering of two of the local fish species of conservative interest (G. kessleri and $G$. albipinnatus).

RÉSUMÉ: Un système de gestion intégrée pour les espèces du genre Gobio - étude de cas pour les rivières Târnave (Transylvanie, Roumanie).

La dynamique spatio-temporelle (2004-2019) des populations des espèces congénères indicatrices de la qualité des habitats Gobio gobio, Gobio kessleri et Gobio albipinnatus (le changement des zones piscicoles caractéristiques des rivières Târnava Mare et Târnava Mică) a relevé une tendance à la dégradation de l'état écologique de ces rivières. Nous avons utilisé l'instrument ADONIS:CE pour concevoir un modèle de gestion intégrée, base sur les besoins et habitats des ces espèces (indicateurs pour un statut favorable de conservation), sur les pressions et menaces. La mise en pratique de ce système de gestion favorisera l'amélioration des habitats lotiques et le retour à l'état favorable de conservation pour les populations locales des deux espèces de poissons d'intérêt conservatif (G. kessleri et G. albipinnatus).

REZUMAT: Sistem integrat de management pentru speciile genului Gobio - studiu de caz râurile Târnave (Transilvania, România).

Dinamica în timp (2004-2019) şi spaţiu a populaţiilor speciilor congenere indicatoare a calităţii habitatelor Gobio gobio, Gobio kessleri şi Gobio albipinnatus (schimbarea zonelor ihtiologice caracteristice în râurile Târnave) relevă o tendinţă descrescătoare a stării ecologice a acestor râuri. A fost utilizat instrumentul ADONIS:CE pentru a construi un model de sistem de management, bazat pe necesităţile de habitat ale acestor specii (indicatori pentru un statut favorabil de conservare), pe presiuni şi ameninţări. Implementarea acestui sistem de management va favoriza ameliorarea habitatelor lotice şi refacerea stării favorabile de conservare pentru populaţiile locale ale celor două specii de peşti de interes conservativ ( $G$. kessleri şi G. albipinnatus). 


\section{INTRODUCTION}

The regular streams and rivers long-term monitoring activities which depends mainly on assessment of physico-chemical elements, can furnish only a partial view on the ecological conditions at the moment of sampling and usually fail to detect long term ecological problems (e.g. habitat fragmentation and alteration, pollution, etc.), and have to be supplemented with different taxa assessment and monitoring; fish being one of the most appropriate such taxa (Joy and Death, 2003, 2004; Jeeva et al., 2011; Potyó and Guti, 2012; Khoshnood, 2014; Rumana et al., 2015; Bănăduc et al., 2016a; Radhi et al., 2017; Kruk et al., 2017).

In the Lower Danube Basin, but not only, the fish can be one of the most important taxonomic group used for lotic systems ecological assessment and monitoring (Staicu et al., 1998; Bănăduc and Curtean-Bănăduc, 2002; Vassilev and Botev, 2008; Momeu et al., 2009; Trichkova et al., 2009; Florea et al., 2014; Bănăduc et al., 2014; Năstase and Oţel, 2017; Kruk et al., 2017). Among fish there are some taxa with particular and significant high ecological indicative values, the Gobio species being a very good example in this respect, they are well known indicators for different rivers' ecological zones, zonation based on these species relative abundance, each river being characterised by different Gobio species/Gobiozones and/or another sequence of these zones (Bănărescu, 1956, 1964, 2000).

Gobio uranoscopus is the most rheophilic species, populating the sub-montane stony sectors of lotic ecosystems, where the water movement is rapid, at a velocity of $70-115 \mathrm{~cm} / \mathrm{sec}$. Gobio kessleri inhabits sandy stretches of lotic ecosystems, usually preferring water movement of 45 to $65 \mathrm{~cm} / \mathrm{sec}$ in lowlands. Gobio albipinnatus lives in places with even slower running water, with movement ranging between 28 and $45 \mathrm{~m} / \mathrm{sec}$ and sediments consisting of fine sand often mixed with mud and/or clay, but never mud only. Gobio gobio is a relatively common species, occupying diverse categories of lotic habitats among other brooks downstream the lower trout zone, as well as slow-flowing lotic habitats. It can also be found in dam lakes; this fish species is more common in the sub-mountain than in the lowland stretches of large lotic ecosystems but it will choose the sectors with slow-moving water, preferring stagnant water sectors, etc. It is the less rheophilic of these Gobio species and also the most resistant to pollution. Based on these specific ecological requirements of the Gobio species the Romanian rivers/lotic sectors in the Lower Danube Basin can be split/belong to eight different categories, with different ecologic characteristics. (Bănărescu, 1956, 1964; Bănăduc, 2007)

The studied Târnava Mare, Târnava Mică and Târnava rivers basin is characterised by three Gobio species zones, namely Gobio kessleri, Gobio albipinnatus, and Gobio gobio (Bănărescu, 1964; Bănăduc, 2005). The human impact (damming, pollution, water amount reduction, riverbed mineral overexploitation, poaching, etc.) has modified the distribution and local abundance of these three gudgeon species, namely the rarefaction of rheophilic species (Gobio kessleri and Gobio albipinnatus), favouring instead the ubiquitous species (Gobio gobio) (Bănăduc, 2005; Curtean-Bănăduc et al., 2001, 2007; Bănăduc and Curtean-Bănăduc, 2012).

Târnava River basin (Fig. 1) is located in the central part of the South-East Carpathian Mountains, in the inner Transylvania Depression, in the southern part of the Târnavelor Plateau. Lotic habitats vary from cool, clear, and forested headwater streams that have coarse volcanic bedrock with accentuated slopes in the mountainous area, transitional coarse substrates in the Sub-Carpathian area, to warmer, sluggish, meandering waters, with low slope gradients and sandy-silty substrates. (Tufescu, 1966; Roşu, 1980; Posea et al. 1983) 


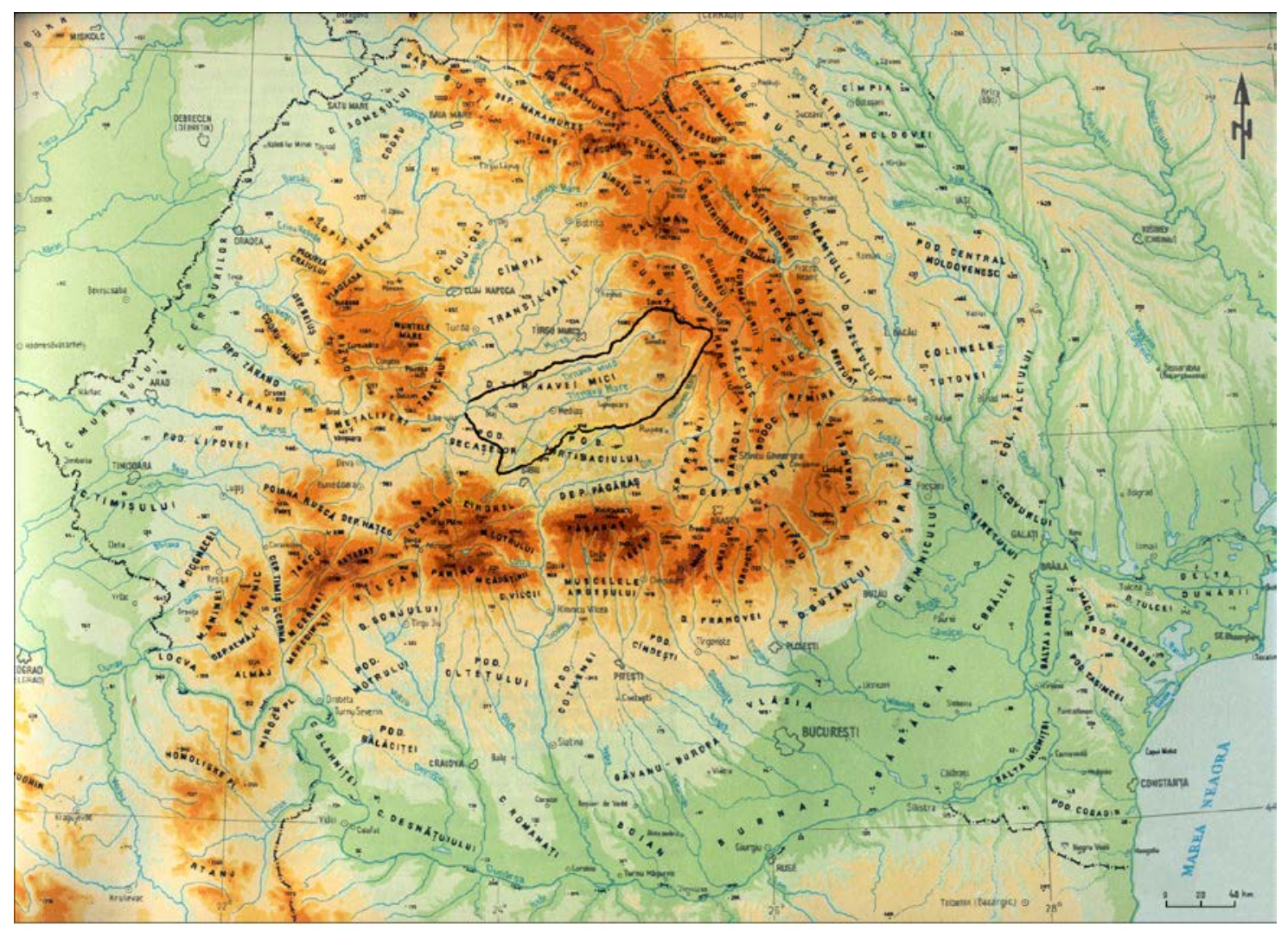

Figure 1: The Târnava River basin (Badea et al., 1983 - modified).

The European Union Habitats Directive, active since 1992, is used in order to shield the continuity of a high variety of plant and animal key species of the old continent. The joining countries have to secure that the indispensable environmental circumstances continue to exist, for the conservation of the species and habitats belonging to the Annex 2 of the Habitats Directive, along with the final goal of conserving (where it is achievable) and improving their ecological status. The studied basins are partially in the Sighişoara-Târnava Mare Natura 2000 site (ROSCI0227). The admission of the proposed Natura 2000 sites depend on clear criteria such as: permanent, pristine and healthy fish populations, typical habitats, favourable geographic positioning, and minimal human impact (Habitats Directive, 1992). A few key elements are promoted through the European Union Natura 2000 initiative to improve the condition of protected areas, including: elaborating specific information; widening the protected areas; institutional capacity progress; relevant specific assessment and monitoring; applicable management activities in complex management programs in the areas with preservation status and surrounding areas (Bănăduc, 2007; Bănăduc et al., 2012).

Gobio kessleri (Dybowski, 1862) (Ord. Cypriniformes; Fam. Cyprinidae), is under the protection of the Bern Convention Annex 3, Habitats Directive Annex 2, and the IUCN Red List. Gobio albipinnatus (Lukasch, 1933) (Ord. Cypriniformes; Fam. Cyprinidae) is under the protection of the Bern Convention Annex 3, Habitats Directive Annex 2, and IUCN Red List. $(*, 1992 ; * *, 1979)$. 
Fish species communities in areas where Gobio kessleri and Gobio albipinnatus were found indicate a diminishing of these populations abundance as a result of human impact. This reduction highlights the diminishing of the natural status of the Târnava Watershed (Bănăduc, 2005; Bănăduc et al., 2016b). This pattern reflects a general degradation of lotic habitats, as a result of human activities and pressures (Bănăduc and Curtean-Bănăduc, 2012).

Stream and river ecosystems are very complex and each represent unique ecological systems (Vannote et al., 1980; Allan 1995; Angelier, 2003), and universal-like management schemes for entire basins are likely not be satisfactory (Boon and Raven, 2012).

In the best way possible, the main ecosystem elements of each basin should be evaluated at the starting point of any management construction procedure. Any universal-like management scheme needs to be adapted to maintain specific habitats and species that are present and need to thrive.

In nature conservation, modelling actions in order to achieve the desired results are for the most part used to acquire a "large-scale picture" of isolated systems and/or actions of distinct domains. The parts of these actions which belong to a process are beneficial in discerning different levels of proper species and habitat management. Using software such as ADONIS:CE, models that help understanding how area of interest management tasks can be developed. Models target on three areas of operation, all essential for the management of an area of interest: 1) to verify the actual status, 2) to evaluate the effects of changings and 3) to propose management systems to improve the present status in a desired way. Finally, various diagrams can be produced to present adapted management elements (Hall and Harmon, 2005).

This study, based on the decreasing favourable conservation status of Gobio kessleri, Gobio albipinnatus populations in Târnava Mare, Târnava Mică and Târnava rivers, highlights the human activities pressures and threats at the basin level. This study uses a particularly created management model to suggest management elements to sustain the improvement of the ecological status for the studied fish species by improving their habitats status. The obtained model integrates habitat initial conditions and specific indicators as a whole functional management system.

\section{MATERIAL AND METHODS}

An adaptable-responsive model of management was projected to build up a suitable management plan that would guard from harm the researched congeneric fish species that are present in the researched area lotic ecosystems, with a priority on indispensible processes. Here we used the software ADONIS:Community Edition (ADONIS:CE) created by the Business Object Consulting (BOC) Group. This software is a free and available type of ADONIS with few restraints (if we have to compare it with the commercial version); using a Business Process Model and Notation (BPMN), a standardized modelling language type those back recognizable processes to be prominenced. ADONIS:CE is usually used as an admission point to Business Process Management. Using compatible notation all these processes can be modelled. $(* * *)$

In order to create an overall vision of the Gobio kessleri and Gobio albipinnatus species - ecological requirements, possible indicators, their favorable conservation status, and management measures to maintain/achieve the favorable conservation state - we used ADONIS: Community Edition, software specialized in modeling business processes. 


\section{RESULTS AND DISCUSSION}

\section{Identified human pressures and threats}

The main common pressures and threats on Gobio kessleri and Gobio albipinnatus populations are: changing/destroying characteristic aquatic habitats (higher or lower speed of water, water depth changes and substratum change negatively affect these species), water pollution, unselective poaching (with toxic substances, electrofishing, and/or illegal nets), the lotic continuum fragmentation due to hydrotechnical works.

\section{Identified specific requirements}

Both adults and juveniles need a significant/close to natural/moderate water flow and depth, with sandy substrata.

\section{Proposed specific habitat indicators}

In the studied lotic ecosystems, main habitat indicators are proposed as explanation for the presence/absence and relative abundance of Gobio kessleri and/or Gobio albipinnatus: average water flowing surface speed (60\% proportion of the river), average water depth (60\% proportion of the river), combined with sandy substratum $(60 \%$ proportion of the river).

\section{Management measures}

Management elements have been a purpose for analytical research, and requirement for the basin managers have to decrease the effects of local and regional numerous pressures and threats. As a consequence there are numerous points of view and models which can vary due to different sources, system and construction intricacies. The indicators of a management system can be built within a six main steps process (Krause and Mertins, 1999): establishing a process value chain model, determining the key factors of success, describing the efficiency indicators, acquiring and confirmation of the information, assessment of the efficiency indicators, and enforcing a constant process.

This pathway relayed on a model based on the learning process which appears while preparing the process maps; and it sets up the need for management elements gathered around the record sheets of management measures. For that reason it is necessary to underline that constructing on the need to discover an indicator set to assess an entity's general performance, the proposed model finds the main value delivery process, to which an indicator set for process evaluation can be nominated, which are induced by identifying the success elements, for the process and for the entity's all-encompassing performance (Miricescu, 2011, 2014).

Corresponding with this model we advocate that the main management measures be: conservation of the natural morphology of the streams and rivers and their banks; riverbed exploitation should be done only outside the lotic habitats characterised by average flow speed, sandy substratum and medium deep water; preserving the vegetation of the basin for sediments control in the basin; conserving the riverine vegetation corridor on a minimum of 100-200 m on both banks for their sediment traps role; water pollution control; guarding a continuous medium level of the flowing water particularly in dry seasons through banning of important water removals; implementing an integrated monitoring system for local and regional fish fauna. 


\section{Adjusted model for the site management}

The characteristics of the two species were modeled using three processes (Fig. 2) as follows: species Gobio kessleri and Gobio albipinnatus - the basic process, Habitat indicators of Gobio kessleri and Gobio albipinnatus species - (sub)process that present the possible indicators in the current status and favorable conservation status and the last (sub)process Management measures for Gobio kessleri and Gobio albipinnatus habitat indicators presenting the management measures that should be taken to preserve the favorable conservation status of species.

\section{Explorer - Hierarchy

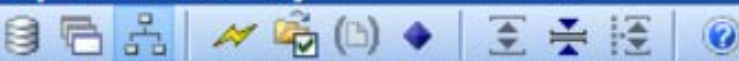 \\ $\exists \Delta$ Species Gobio kessleri and Gobio albipinnatus \\ $\square \Delta$ Habitat indicators of Gobio kessleri and Gobio albipinnatus species \\ $\Delta$ Management measures for Gobio kessleri and Gobio albipinnatus habitat indicators}

Figure 2: Species Gobio kessleri and Gobio albipinnatus

- process hierarchy.

\section{Model description}

The main features of the Gobio kessleri and Gobio albipinnatus have been modeled using the most common objects in the ADONIS:CE library, namely the process start $\Delta$, activities $\square$, decisions $\Delta$, parallelism $\Delta$, merging $D$, subprocess (all are processes that call inside another process, it works as a hyperlink) $\Delta$ and end of the process $\mathrm{O}$.

The basic process is Species Gobio kessleri and Gobio albipinnatus (Fig. 3), a process in which are presented the habitat type, the possible requirements for habitats, field observations, pressures and threats to species. With parallelism and merging objects are modeled the possible indicators of the two species, according to the Habitat indicators of Gobio kessleri and Gobio albipinnatus species subprocess to be analyzed. The pressures and threats of the researched fish species are highlighted in the two borders $(\square)$. 


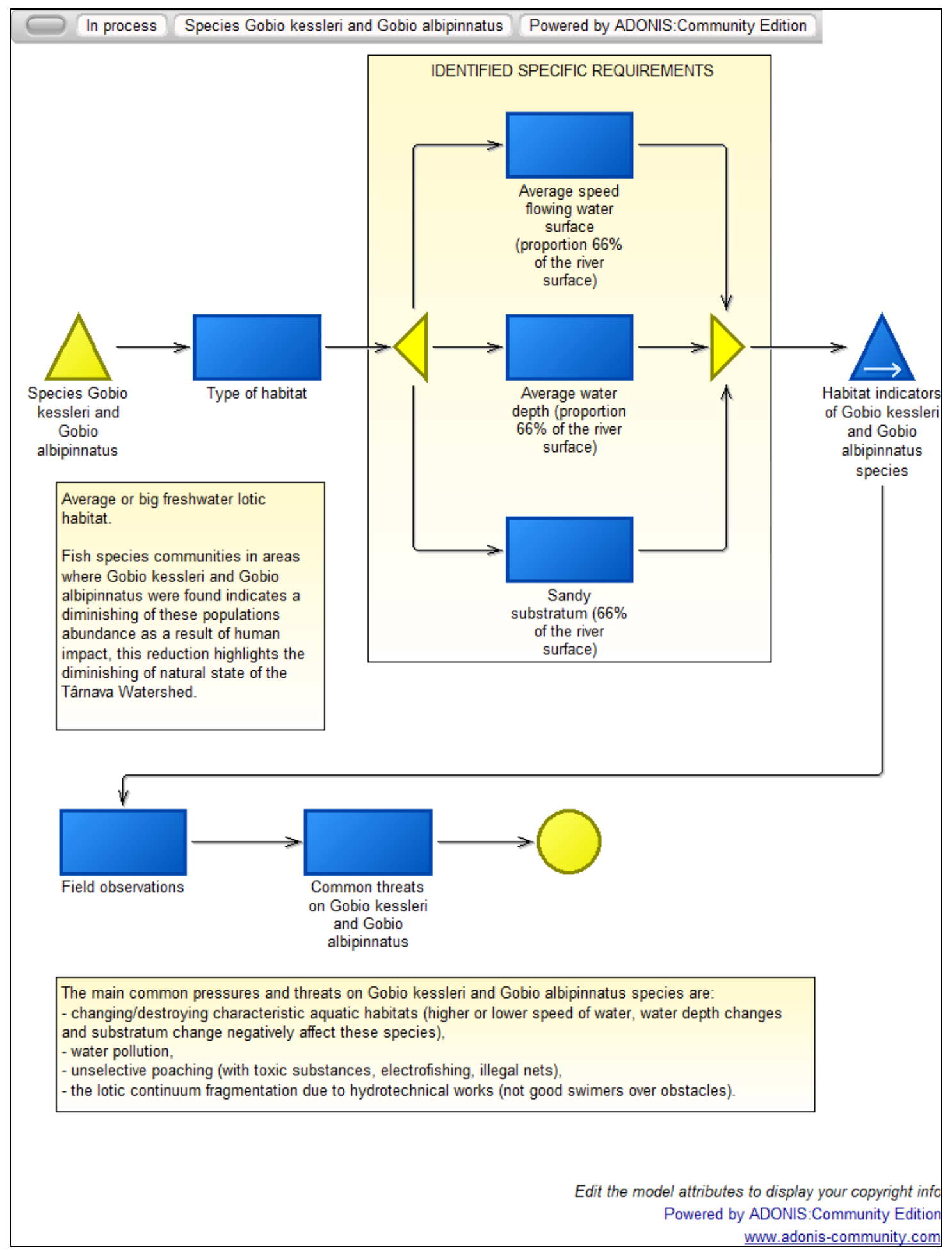

Figure 3: Species Gobio kessleri and Gobio albipinnatus - main process. 
In the subprocess Habitat indicators of Gobio kessleri and Gobio albipinnatus species (Fig. 4) the possible indicators are shaped - measured on the ground or taken from other sources - to verify whether these species indicators fulfil the favourable conservation status. Each indicator is assigned a decision. Each decision is assigned a variable (indicator name) and a random generator (assigns value of the variable). For each indicator there are data such as the actual status percentage. This percentage is compared by decisions with the percentage of favourable conservation status. It is practically checked whether the actual status represents a favourable conservation status.

If the first indicator is in favourable conservation status (variable = "Speed_flowing_water_surface", probability on the "YES" branch $=66 \%$ ), the process continues with the following indicator. If this indicator is not in favourable conservation status (variable = "Speed_flowing_water_surface", probability on the "NO" branch $=34 \%$ ), then it must go through the subprocess with the management measures $\Delta$. The same goes for the second indicator: if it is in the favourable conservation status (variable = "Water_depth", probability on the "YES" branch $=66 \%$ ), then the process continues with the third indicator (variable = "Sandy_substratum", probability on the "YES" branch $=50 \%$, probability on the "NO" branch $=50 \%$ ), and if not (variable = "Water_depth", probability on the "NO" branch = 34\%), then call the subprocess with the management measures. This cycle repeats itself and only comes out when all indicators meet the favourable conservation status through the activity "Implementation of a seasonal integrated monitoring system" and the process ends.

The last subprocess modelled here is "Management measures for Gobio kessleri and Gobio albipinnatus habitat indicators" (Fig. 5). Based on the acquired data, the major management elements that should be followed to guarantee the favourable conservation status of the species have been underlined. Among the most important management measures we mention: preservation of the natural morfodynamics of the riverbeds - it is recommended to prohibit the construction/layouts which have the effect of changing the flow rate regime and the composition of the bed substrate; establish a complex system of fish ladders to diminish the negative effect of the loose discontinuities created by the existing dams, lakes and semilentic areas; the exploitation of mobile aggregates in riverbeds should not be allowed, with the aim of preserving the habitat characteristic of this species; in all sectors of interest rivers, the phenomenon of poaching is very intense and quasi-permanent, which makes it more effective to control; prohibition of abandonment of waste of any nature in the wetland and wetlands adjacent to the watercourses. 


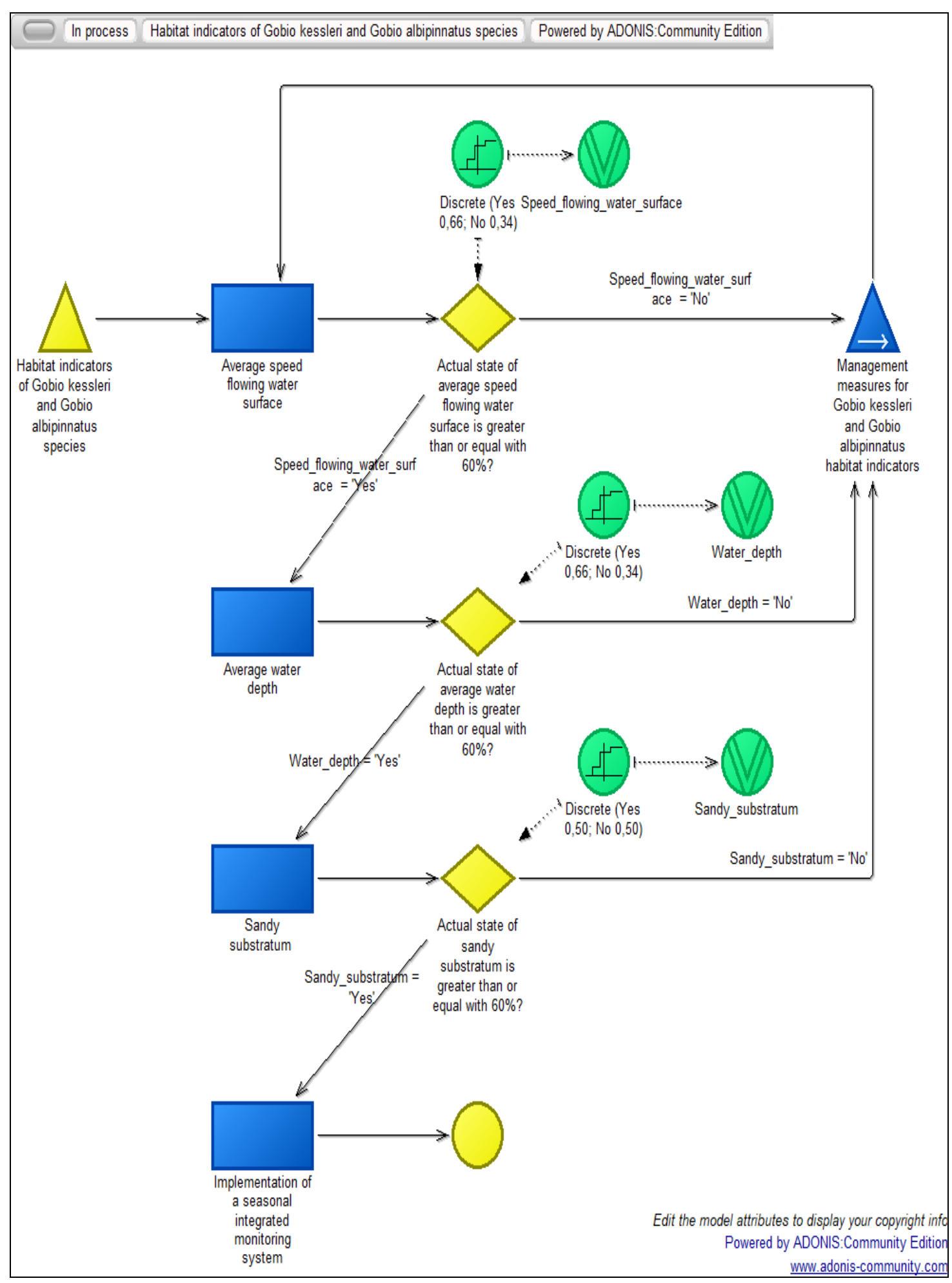

Figure 4: Habitat indicators of Gobio kessleri and Gobio albipinnatus species. 
In process Management measures for Gobio kessleri and Gobio albipinnatus habitat indicators Powered by ADONIS:C,

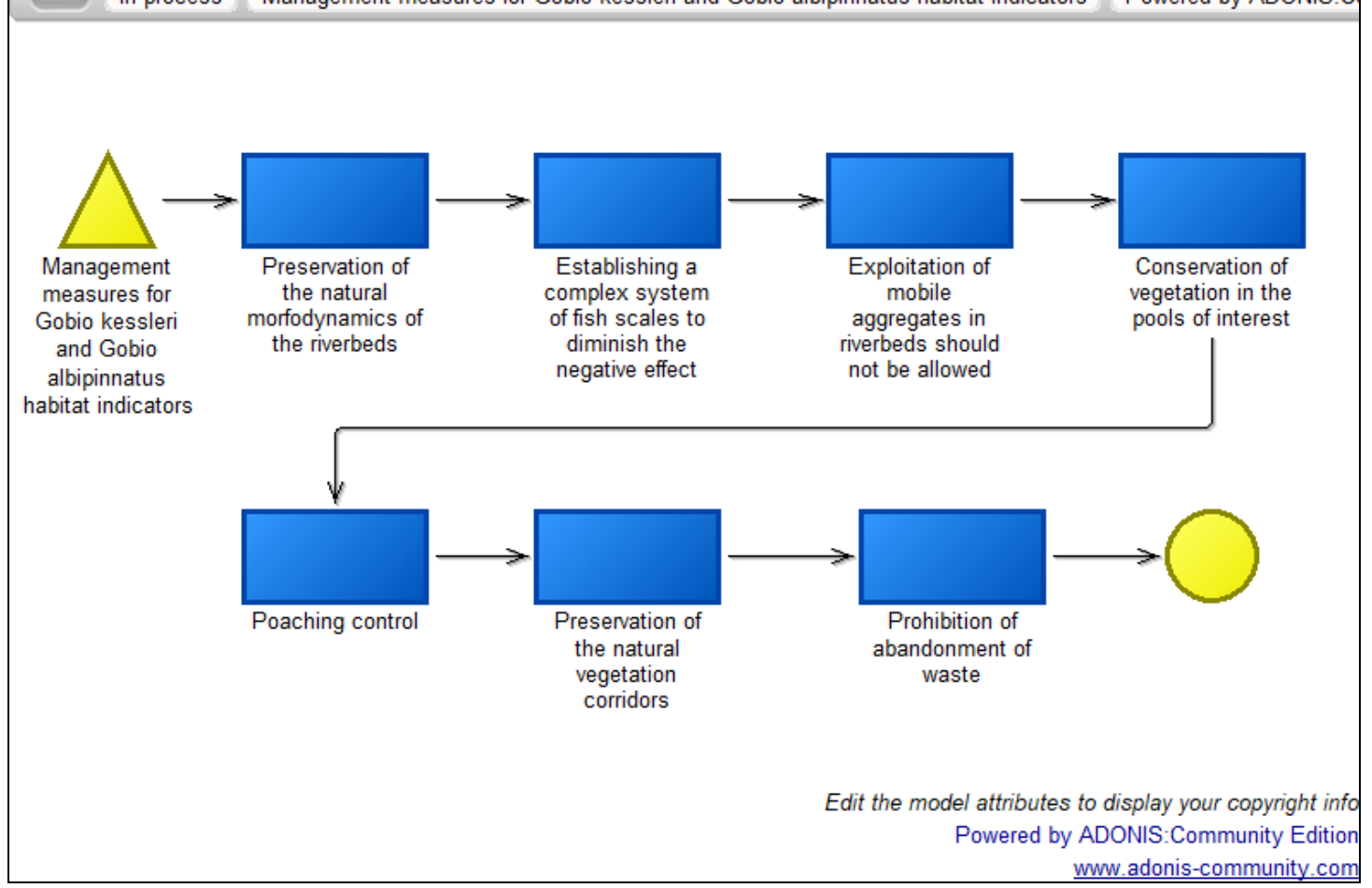

Figure 5: Management measures for Gobio kessleri and Gobio albipinnatus habitat indicators.

\section{CONCLUSIONS}

The lotic habitats quality indicative congeners species Gobio gobio, Gobio kessleri and Gobio albipinnatus populations dynamic in time (2004-2019) and space (shifting characteristic fish zones in Târnave rivers) reveals a decreasing trend in these rivers habitats ecologic status.

The ADONIS:CE tool has been used, to build a backing management system model, based on these indicative fish species habitat needs, the indicators for favourable conservation status, pressures and threats.

This management system implementation in the field will favour the ecological status recovering of the two of fish species of conservative interest (G. kessleri and G. albipinnatus) based on the amelioration of their natural lotic habitats ecologic status. 


\section{ACKNOWLEDGEMENTS}

The authors of this paper wish to thank to Dr. Popa E. M. for his support in informatics, and to the numerous fishers of the Târnava Basin for their kind cooperation during the research. This study data was obtained in the research period for POS Mediu, priority ax 4 project code SMIS - CSNR 17049 "Pentru Comunităţi Locale și Natură - Bazele managementului integrat Natura 2000 în zona Hârtibaciu - Târnava Mare Olt (PH+ PRO MANAGEMENT Natura 2000)" and also for Project ID 66243, SIDPOP "Instrument suport pentru luarea deciziilor în domeniul managementului poluanţilor organici persistenţi. Studiu de caz: Bazinul hidrografic Mureş”, finanţat în cadrul programului R004 "Reducerea substanţelor periculoase", prin Mecanismul Financiar al Spaţiului Economic European (SEE). 


\section{REFERENCES}

1. Allan J. D., 1995 - Stream Ecology: structure and function of running waters, Chapman and Hall, London, 388.

2. Angelier E., 2003 - Ecology of streams and rivers, Science Publishers, Inc., Enfield, 215.

3. Badea L., (ed.), 1983 - Geografia României, I, Geografia Fizică, Edit. Academiei Române, 662. (in Romanian)

4. Bănăduc D. and Curtean-Bănăduc A., 2002 - A biotic integrity index adaptation for a Carpathian (first - second order) river assessment, Acta oecologica - Studii şi Comunicări de Ecologie şi Protecţia Mediului, IX, 1-2, Edit. Universităţii "Lucian Blaga” din Sibiu, ISSN 1221-5015, 77-95.

5. Bănăduc D., 2005 - Transylvanian Review of Systematical and Ecological Research, 2, The Târnava River Basin, Fish associations - habitat quality relation in the Târnave Rivers (Transylvania, Romania), ecological assessment, 123-136.

6. Bănăduc D., 2007 - Middle Olt River (Transylvania, Romania) - Special area for conservation (Natura 2000 Site) proposal for Cobitis taenia Risso, 1827 and associated fish species, Acta Ichtiologica Romanica, II, 37-42.

7. Bănăduc D. and Curtean-Bănăduc A., 2012 -Fish communities structural and functional aspects - Târnava River basin (Transylvania, Romania) case study, Transylvanian Review of Systematical and Ecological Research, 14, The Wetlands Diversity, Edit. Universităţii “Lucian Blaga” din Sibiu, ISSN 1841-7051, 129-150.

8. Bănăduc D., Nagy A. and Curtean-Bănăduc A., 2012 - New SCIS proposal regarding the ichthyofauna after the Continental Biogeographic Seminar for Romania, Sibiu (Transylvania, Romania), 9-12 June 2008, Acta Oecologica Carpatica, V, 145-158.

9. Bănăduc D., Curtean-Bănăduc A., Lenhardt M. and Guti G., 2014 - "Porţile de Fier"/“Iron Gates” Gorges area (Danube) fish fauna, Transylvanian Review of Systematical and Ecological Research, 16, The "Iron Gates” Nature Park, 171-196.

10. Bănăduc D., Rey S., Trichkova T., Lenhardt M. and Curtean-Bănăduc A., 2016a - The Lower Danube River - Danube Delta - North West Black Sea: A pivotal area of major interest for the past, present and future of its fish fauna - A short review, Science of the Total Environment, 545-546, 137-151, DOI: 10.1016/j.scitotenv.2015.12.058, ISSN 0048-9607, eISSN 1879-1026.

11. Bănăduc D., Pânzar C., Bogorin P., Hoza O. and Curtean-Bănăduc A., 2016b - Human impact on Târnava Mare River and its effects on aquatic biodiversity, Acta Oecologica Carpatica, IX, 189-198.

12. Bănărescu P. M., 1964 - Fauna R. P. R., Pisces-Osteichthyes, XIII, Edit. Academiei Române, 959. (in Romanian)

13. Bănărescu P. M., 1956 - Importanţa speciilor de Gobio ca indicatori de zone biologice în râuri, Buletinul Institutului de Cercetări Piscicole, 15, 3, 53-56.

14. Bănărescu P. M., 2000 - The gudgeon species of the genus Gobio as indicators of ecological zones in rivers (Pisces, Cyprinidae), Proceedings of the Institute of Biology, III, 147-152.

15. Boon P. J. (ed.) and Raven (co-ed.) P. J., 2012 - River conservation and Management, ISBN 978-0-470-68208-1, John Wiley and Sons, Ltd., 432.

16. Curtean-Bănăduc A., Bănăduc D. and Sîrbu I., 2001 - Oameni şi râuri împreună. Impactul antropic asupra Târnavelor şi Ampoiului, Edit. „Mira Design” Sibiu, ISBN 973-8232-32-5, 86. (in Romanian)

17. Curtean-Bănăduc A., Bănăduc D. and Bucşa C., 2007 - Watersheds Management (Transylvania, Romania) - implications, risks, solutions, Strategies to enhance environmental Security in transition countries, NATO Science for Peace and Security Series C-Environmental Security, Springer, 225-238, DOI: 10.1007/978-1-4020-5996-4-17, ISSN 1971-4668, ISBN 978-1-4020-5994-0.

18. Florea L., Strătilă S. D. and Costache M., 2014 - The assessment of community interest fish species from protected area ROSCI0229, Transylvanian Review of Systematical and Ecological Research, 16.1, The Wetlands Diversity, 73-96. 
19. Hall C. and Harmon P., 2005 - The Enterprise Architecture, Process Modeling and Simulation Tools Report, Version 1.1 (2005) November.

20. Jeeva V., Kumar S., Verma D. and Rumana H. S., 2011 - River fragmentation and connectivity problems in Gange River of upper Himalayas: the effect on the fish communities (India), Transylvanian Review of Systematical and Ecological Research, 12, The Wetlands Diversity, 75-90.

21. Joy M. K. and Death R. G., 2003 - Biological assessment of rivers in the Manawatu-Wanganui region of New Zealand using a predictive macroinvertebrate model, New Zealand Journal of Marine and Freshwater Research, 33, 367-379.

22. Joy M. K. and Death R. G., 2004 - Predictive modelling and spatial mapping of freshwater fish and decapod assemblages using GIS and neural networks, Freshwater Biology, 49, 1036-1052.

23. Khoshnood Z., 2014 - Identification and study of fish species in Karkheh River (Iran), Transylvania Review of Systematical and Ecological Research, 16.2, 97-106.

24. Krause O. and Mertins K., 1999 - Performance management, in Mertins K., Krause O. and Schallock O., Global Production Management, Proceedings of the IFIP, WG5.7 International Conference on Advances in Production Management Systems, September, 243-251.

25. Kruk A., Ciepłlucha M., Zięba G., Błońska D., Marsyał L., Tybulczuk S., Tszydel M. and Penczak T., 2017 - Disturbed fish fauna zonation as an indicator of large-scale human impact: A case study (2011-2012) of the large, lowland Warta River, Poland, Journal of Applied Ichthyology, DOI: 10.1111/jai.13297, 174-188.

26. Miricescu D., 2011 - Study on temporal influences on management and managers of business organizations, Proceedings of RMEE, Todesco Publising House, 479-490.

27. Miricescu D., 2014 - Semnele şi amprenta timpului asupra managementului contemporan, Edit. Universităţii "Lucian Blaga" din Sibiu, Sibiu, 69-88. (in Romanian)

28. Momeu L., Battes K., Battes K., Stoica I., Avram A., Cîmpean M., Pricope F. and Ureche D., 2009 - Algae, macroinvertebrate and fish communities from the Arieş River catchment area (Transylvania, Romania), Transylvanian Review of Systematical and Ecological Research, 7, The Arieş River Basin, 149-181.

29. Năstase A. and Oţel V., 2017 - Fish fauna status of the Natura 2000 sites proposed as new or for extension in the rivers Someş and Mureş (Romania), Transylvanian Review of Systematical and Ecological Research, 19.3, The Wetlands Diversity, 57-74.

30. Posea G. (ed.), 1983 - Enciclopedia Geografică a României, Edit. Ştiinţifică şi Enciclopedică, 690-691, Bucureşti. (in Romanian)

31. Potyó I. and Guti G. 2012 - Requirements for representative sampling for fluvial fish assemblages - literary review, Opuscula Zoologica, Budapest, 43, 2, 203-209.

32. Radhi A. M., Rohasliney and Zarul H., 2017 - Fish composition and diversity in Perak, Galas and Kelantan rivers (Malaysia) after the major flood of 2004, Transylvanian Review of Systematical and Ecological Research, 19.3, The Wetlands Diversity, 41-56.

33. Roşu A., 1980 - Geografia Fizică a României, Edit. Didactică şi Pedagogică, 1980, 483, Bucureşti. (in Romanian)

34. Rumana H. S., Jeeva V. and Kumar S., 2015 - Impact of the Low Head Dam/Barrage on fisheries - a case study of Giri River of Yamuna Basin (India), Transylvanian Review of Systematical and Ecological Research, 17.2, The Wetlands Diversity, 119-138.

35. Staicu G., Bănăduc D. and Găldean N., 1998 - The structure of some benthic macroinvertebrates and fishes communities in the Vişeu Watershed, Maramureş, Romania, Travaux du Museum National d Histoire naturelle Grigore Antipa, Bucureşti, XL, 587-608.

36. Trichkova T., Stefanov T., Vassilev M. and Zivkov M., 2009 - Fish species diversity in the rivers of the north-west Bulgaria; Transylvanian Review of Systematical and Ecological Research, 8, The Wetlands Diversity, 161-168. 
37. Tufescu V., 1966 - Subcarpaţii şi depresiunile marginale ale Transilvaniei, Edit. Ştiinţifică, 1966, Bucureşti. (in Romanian)

38. Vannote R. L., Minshall G. W., Cummins K. W., Sedell J. R., Cushing C. E., 1980 - The river continuum concept, Canadian Journal of Fisheries and Aquatic Sciences, 37, 130-137.

39. Vassilev M. and Botev I., 2008 - Assessment of the ecological status of some Bulgarian rivers from the Aegean Sea basin based on both environmental and fish parameters, Transylvanian Review of Systematical and Ecological Research, 6, The Wetlands Diversity, 71-80.

40. *, 1992 - Council Directive 92/43/EEC of 21 May 1992 on the conservation of natural habitats and of wild fauna and flora.

41. **, 1979 - Berne Convention on the Conservation of European Wildlife and Natural Habitats.

42. $* * *$ - http://www.boc-group.com/products/adonis/bpmn-method 